\title{
Magzati-újszüilöttkori fejlődési rendellenességek praenatalis ultrahangvizsgálatának eredményessége, a nehézségi és a bizonytalansági faktorok vizsgálata
}

\author{
Erős Fanni Rebeka dr. - Beke Artúr dr. \\ Semmelweis Egyetem, Általános Orvostudományi Kar, I. Szülészeti és Nőgyógyászati Klinika, Budapest
}

\begin{abstract}
Bevezetés és célkitüzés: A magzati fejlődési rendellenességek születéskori prevalenciája 2-3\% körül van. Célunk a praenatalis ultrahangvizsgálat hatékonyságának az elemzése volt a fejlődési rendellenességek felismerésében.

Módszer: Vizsgálatunk során hét év anyagában 1200, fejlődési rendellenességben szenvedő magzat praenatalis ultrahang- és postnatalis klinikai, illetve fetopatológiai adatait dolgoztuk fel.

Eredmények: Ezerkétszáz, fejlődési rendellenességben érintett magzat adatait dolgoztuk fel. Az anyai átlagéletkor a szülés/vetélés idején 29,96 $\pm 5,88$ év volt. Az 1200-ból 671 esetben végződött szüléssel a várandósság, a gesztációs kor átlaga a szülés idején 35,26 \pm 4,2 hét volt, míg a magzatok súlya 2408,67 $\pm 944,41$ g. Ötszázhuszonkilenc vetélés fordult elő, a gesztációs kor átlaga 19,88 \pm 2,53 hét volt. Az 1200 magzatból 73-nál fordult elő kromoszómarendellenesség, 211 esetben pedig multiplex malformatio. Megállapíthattuk, hogy a magzati craniospinalis rendellenességek és mellkasi eltérések nagy hatékonysággal vizsgálhatók a méhen belüli magzatnál (72,65\% és 67,7\%). Magas szenzitivitással tudtuk kimutatni a hasi malformatiókat $(59,58 \%)$, az urogenitalis rendellenességeket $(54,55 \%)$, illetve a végtag- és csontrendszeri eltéréseket (50\%). Ezzel szemben az arc és nyak rendellenességeinek kimutatása alacsony hatékonyságú volt $(31,85 \%)$.

Következtetések: Az esetek körülbelül felében egyezett meg a postnatalisan/vetélést követóen talált rendellenesség a praenatalisan diagnosztizált magzati anomáliával. Az eredményeink azt igazolják, hogy az ultrahangvizsgálat a congenitalis malformatiók diagnosztikájában fontos szerepet játszik, azonban valamennyi fejlődési rendellenesség kimutatását nem teszi lehetővé.
\end{abstract}

Orv Hetil. 2017; 158(45): 1794-1801.

Kulcsszavak: magzati fejlődési rendellenesség, újszülöttek fejlődési rendellenessége, ultrahangvizsgálat

\section{Effectiveness of prenatal ultrasound in fetal and neonatal malformations and examination of difficulty and uncertainty factors}

Introduction and aim: The birth prevalence of congenital malformations is around 2-3\%. The aim of this study was to examine the efficacy of ultrasound diagnostics in detecting congenital malformations.

Method: We have processed the prenatal sonographic and postnatal clinical details of 1867 inborn abnormalities in 1200 fetuses over a 7 -year period.

Results: The mean maternal age upon delivery/abortion was $29.96 \pm 5.88$ years. In 671 cases, the pregnancy concluded in delivery with a mean gestational age of $35.26 \pm 4.2$ weeks and mean weight of $2408.67 \pm 944.41 \mathrm{~g}$. In case of the 529 abortions the mean gestational age was $19.88 \pm 2.53$ weeks. Seventy-three fetuses were chromosomally abnormal, while 211 had multiple malformations. Prenatal ultrasound was highly sensitive in the detection of central nervous system and thoracic anomalies in utero $(72.65 \%$ vs. $67.7 \%$ sensitivity). The detection rate was high in case of abdominal (59.58\%), urogenital (54.55\%), and limb/skeletal (50\%) malformations as well. However, the diagnosis of face/neck anomalies was somewhat less efficient (31.85\%). 
Conclusions: In approximately half of the cases, postnatally diagnosed abnormalities coincided with the prenatally discovered congenital malformations. The results have confirmed that ultrasonography plays an important role in diagnosing malformations prenatally but it fails to detect all of the developmental abnormalities.

Keywords: prenatal ultrasound, fetal malformations, newborn malformations

Erös FR, Beke A. [Effectiveness of prenatal ultrasound in fetal and neonatal malformations and examination of difficulty and uncertainty factors]. Orv Hetil. 2017; 158(45): 1794-1801.

(Beérkezett: 2017. augusztus 22.; elfogadva: 2017. szeptember 18.)

\section{Rövidítések}

$\mathrm{F}(\mathrm{B})$ = bizonytalansági faktor; $\mathrm{F}(\mathrm{N})$ = nehézségi faktor

A magzati fejlődési rendellenességek születéskori prevalenciája 2-3\% körül van [1-3]. A magzati fejlődési rendellenességek felismerésében mai napig legnagyobb szerepe az ultrahangszúrésnek, illetve a célzott ultrahangvizsgálatoknak van. Az ultrahang a legelterjedtebben használt diagnosztikus eszköz a szülészetben, azon belül is a fejlődési rendellenességek kimutatásában. Fontos azonban annak ismerete, hogy melyek azok a rendellenességek, amelyek nagy bizonyossággal kimutathatóak már praenatalisan is, illetve melyek azok, amelyeknek kimutatása csak részben vagy esetleg egyáltalán nem lehetséges a szülést megelőzően.

Az irodalmi adatok alapján magas szenzitivitással mutathatóak ki az agy és gerincvelő rendellenességei, valamint egyes cardiovascularis malformatiók [3-5]. Alacsony azonban az ultrahang hatékonysága az arc, a végtagok, valamint a genitalék eltéréseinek diagnosztizálásában $[2,6,7]$. A magzati rendellenességek ultrahangvizsgálatával több hazai közlemény is foglalkozik [8-10].

A várandósok magas, sokszor irracionális elvárása, hogy minden rendellenesség már korán és teljes mértékben felismerhető legyen a várandósság során, gyakran kártérítési perekhez vezethet. Elengedhetetlen tehát a megfelelő tájékoztatás, amihez nélkülözhetetlen, hogy a tájékoztatást végzők is naprakész tudással rendelkezzenek az ultrahangvizsgálatok hatékonyságát illetően. A praenatalis diagnosztika óriási szakmai felelősséggel is jár, hiszen egy esetleges pontatlan diagnózisnak jelentős következményei lehetnek mind a magzatra, mind pedig a családra nézve. Fontos tehát annak vizsgálata, hogy jelenleg a magyarországi terhesgondozási rendszer ultrahangprotokollja mellett milyen arányban sikerül kimutatni az egyes rendellenesség-csoportokat.

Célunk a praenatalis ultrahangvizsgálatok hatékonyságának vizsgálata volt a fejlődési rendellenességek felismerésében. Célul tűztük ki, hogy megvizsgáljuk, mennyire jellemezték jól az általunk bevezetett új paraméterek, így a bizonytalansági faktor $[\mathrm{F}(\mathrm{B})]$ és nehézségi faktor $[\mathrm{F}(\mathrm{N})]$ a rendellenességek felismerésének nehézségeit.

\section{Betegek és módszer}

Vizsgálatunk során 2006-2012 között az I. Szülészeti és Nőgyógyászati Klinika anyagában azokat az eseteket dolgoztuk fel, ahol a fetopatológiai leletben, illetve postnatalis vizsgálat során fejlődési rendellenességeket diagnosztizáltak. A vizsgálat során a praenatalis ultrahangleleteket, a postnatalis klinikai adatokat, valamint a fetopatológiai leleteket dolgoztuk fel.

Az I. Szülészeti és Nőgyógyászati Klinika praenatalis diagnosztikai centrumként múködik, az ország számos részéról utalnak klinikánkra várandósokat vizsgálatra, konzíliumba a progresszív betegellátás keretében. A genetikai tanácsadáson a munkánk során - az egyéb tanácsadási szituációk mellett - gyakran találkozunk a méhen belüli magzatnál kimutatott ultrahangeltéréssel. Ezen eltérések lehetnek:

1. Más intézetben elvégzett ultrahangvizsgálat során észlelt és a klinikánkon a genetikai tanácsadás keretében elvégzett ultrahangvizsgálat alkalmával megerősített eltérések.

2. Klinikánkon a rutin-terhesgondozás keretében, az ultrahangszürésen átesett várandósoknál kimutatott ultrahangeltérések, és emiatt a genetikai tanácsadásra utalt esetek.

3. Egyéb okból (például biokémiai paraméterekben észlelt eltérés miatt) a genetikai tanácsadásunkra utalt, és az általunk elvégzett ultrahangvizsgálat során észlelt eltérések.

4. Egyéb anyai és magzati okból elvégzett echokardiográfia, magzati szív-ultrahangvizsgálat során észlelt eltérések.

Külön megvizsgáltuk a kromoszómaeltéréshez társult, a multiplex malformatio részeként előfordult fejlődési rendellenességeket, illetve azokat az eseteket, amelyekben a rendellenesség nem társult más szervrendszer eltérésével. Az irodalmi adatokkal való összehasonlíthatóság érdekében a rendellenességeket az EUROCAT tanulmány szempontjait figyelembe véve csoportosítottuk. A rendellenességeket hat föcsoportba soroltuk: 1. agy és gerincvelő; 2. arc és nyak; 3. mellkas; 4. has és hasfal; 5. vese és nemi szervek; 6 . végtagok eltérései.

Az ultrahangvizsgálatok az I. Szülészeti és Nőgyógyászati Klinika Ultrahang Laboratóriumában Philips ${ }^{\circledR}$ HD 
IIXE (Philips Ultrasound) és GE Voluson ${ }^{\circledR} 730 \mathrm{PRO}$ (GE Medical System Kretztechnik GmbH \& Co OHG), valamint Medison SA9900 ultrahangkészülékkel történtek (Medison Co., LTD). A vizsgálatok a Magyar Szülészeti-Nőgyógyászati Ultrahang Társaság által kidolgozott szakmai protokolloknak megfelelően történtek (Szülészeti terhességi transabdominalis ultrahangvizsgálat - 2003. 02. 10; Magzati echokardiográfia - 2003. 02. 10.; A terhesség során javasolt ultrahangvizsgálatok - 2003. 02. 10.).

A betegeket három csoportra osztottuk: az első csoportba (I.) soroltuk azokat a magzatokat, akiknél a praenatalis ultrahangvizsgálat és a postnatalis/fetopatológiai vizsgálati eredmények teljes egyezést mutattak; a második csoportba (II.) kerültek azok az esetek, ahol a fejlödési rendellenesség csak részben került felismerésre; a harmadik csoport (III.) betegeinél nem került felismerésre az eltérés a születés/vetélés előtt.

Részben felismertnek tekintettük azokat az eseteket, ahol az ultrahangvizsgálat során felismerésre került az adott szervnek a rendellenessége, azonban a megszületés/vetélés után elvégzett vizsgálatok alapján - a feltételezett diagnózishoz képest - a végleges diagnózis eltérő volt. Példaként hozhatjuk fel az agyi eltérések között, ha az ultrahangvizsgálatok során oldalkamra-tágulatot vagy az agykamra alaki eltérését írta le az ultrahang, de a postnatalis vizsgálatok corpus callosum agenesiát/dysgenesiát igazoltak. Hasonlóan előfordult például végtag- és csontosodás-rendellenességnél, hogy az ultrahangvizsgálat alapján dongaláb gyanúja merült fel, azonban a megszületés/vetélés után elvégzett kivizsgálás során arthrogryposis igazolódott.

A statisztikai feldolgozás során két új paramétert vezettünk be az egyes rendellenességek kimutathatóságának jellemzésére.

A bizonytalansági faktor esetén a részben felismert esetek számát osztottuk a felismert esetek számával (teljesen és részben felismert esetek számának összege). Tehát ezzel a paraméterrel azt vizsgáltuk, hogy a felismert esetek hány százaléka volt részben felismert.

$$
F(B)=\frac{n(\text { részben felismert })}{n(\text { felismert })}
$$

A másik paraméter, a nehézségi faktor esetén a fel nem ismert esetek számát osztottuk a felismert esetek számával. Ezzel a második paraméterrel azt vizsgáltuk, hogy a nem felismert esetek száma hogyan aránylott a felismert esetek számához.

$$
F(N)=\frac{n(\text { nen felismert })}{n(\text { felismert })}
$$

A bizonytalansági és a nehézségi faktor számításánál alacsonynak tekintettük az értéket, ha 0,5 alatt volt, magasnak tekintettük az értéket, ha nagyobb vagy egyenló volt 0,5 -del, de kisebb volt egynél, nagyon magasnak vettük az értéket, ha több volt vagy egyenlő eggyel.

\section{Eredmények}

Az I. Szülészeti és Nőgyógyászati Klinikán 2006-2012 között 25700 újszülött jött világra és 8580 vetélés történt. A 8580 vetélésből 5628 esetben indukált, míg 2952 esetben spontán vetélés következett be. A vetélések nagy része, 7453 eset (4822 indukált és 2631 spontán vetélés) az első trimeszterben történt, míg 1127 vetélés a második trimeszterben (806 indukált és 321 spontán vetélés). Összesen 1616 magzatnál fordult elő a jelzett időszakban valamilyen fejlődési rendellenesség.

Az 1616 esetból 416-ot kizártunk a vizsgálatból. Egyrészt kizárásra kerültek azok az esetek, amelyeknél nem történt ultrahangvizsgálat és csak a szülés/vetélés után került felismerésre a rendellenesség, összesen 68 ilyen eset került kizárásra. A 68 esetből 61 szülés és hét vetelés volt. Hét esetben multiplex rendellenesség, 25 mellkasi, hét hasi, 11 urogenitalis, 20 craniofacialis, hét végtagi, négy hydrops fordult elő. Az 1616 esetből további 348-at kizártunk a vizsgálatból, mert ezen magzatoknál kizárólag kromoszómaeltérés és/vagy minor rendellenességek fordultak elö, és nem társultak major ultrahangeltéréssel. Az 1616 esetből tehát 1200 magzat adatait dolgoztuk fel.

Az 1200 magzatból 644 fiú és 515 leány volt, 41 esetben pedig nem volt ismert a nem. Az anyai átlagéletkor a szülés/vetélés idején $29,96 \pm 5,88$ év volt. A terhesség

\begin{tabular}{|c|c|c|}
\hline Ikerpár & Magzat & Rendellenesség \\
\hline \multirow[t]{4}{*}{1.} & A & Anencephalia \\
\hline & & AVSD \\
\hline & & Pulmonalis stenosis \\
\hline & $\mathrm{B}$ & Fallot-tetralógia \\
\hline \multirow[t]{5}{*}{2.} & A & ASD \\
\hline & & Pyelectasia \\
\hline & & Ureter és pyelon duplex \\
\hline & $\mathrm{B}$ & Pyelectasia \\
\hline & & Ren duplex \\
\hline \multirow[t]{3}{*}{3.} & A & Komplett nagyér-transpositio \\
\hline & & Situs inversus \\
\hline & $\mathrm{B}$ & Situs inversus \\
\hline \multirow[t]{4}{*}{4.} & A & Belek malrotatiója \\
\hline & & Ductus omphaloentericus persistens \\
\hline & & Invaginatio intestini \\
\hline & $\mathrm{B}$ & Palatoschisis \\
\hline \multirow[t]{2}{*}{5.} & A & Palatoschisis \\
\hline & $\mathrm{B}$ & VSD \\
\hline \multirow[t]{3}{*}{6.} & A & Facialis dysmorphia \\
\hline & & VSD \\
\hline & $\mathrm{B}$ & Duodenumatresia \\
\hline
\end{tabular}

1. táblázat | Ikerpároknál előforduló rendellenességek 
2. táblázat |Craniospinalis rendellenességek felismerésének bizonytalansági faktora $\mathrm{F}(\mathrm{B})$ és nehézségi faktora $\mathrm{F}(\mathrm{N})$

\begin{tabular}{|c|c|c|c|c|c|c|c|c|c|}
\hline \multirow[t]{2}{*}{ Rendellenesség típusa } & \multirow[t]{2}{*}{ Esetszám } & \multicolumn{2}{|c|}{ I. teljes egyezés } & \multicolumn{2}{|c|}{$\begin{array}{c}\text { II. részleges } \\
\text { egyezés }\end{array}$} & \multicolumn{2}{|c|}{ III. eltérés } & \multirow{2}{*}{$\begin{array}{c}\text { Bizonytalan- } \\
\text { sági faktor } \\
\text { F(B })^{*} \\
\text { II } / \mathrm{I}+\text { II }\end{array}$} & \multirow{2}{*}{$\begin{array}{c}\text { Nehézségi } \\
\text { faktor } \mathrm{F}(\mathrm{N}) \text { * } \\
\text { III/I + II }\end{array}$} \\
\hline & & $\mathrm{n}$ & $\%$ & $\mathrm{n}$ & $\%$ & $\mathrm{n}$ & $\%$ & & \\
\hline Ventriculomegalia/hydrocephalus & 115 & 91 & $79,13 \%$ & 6 & $5,22 \%$ & 18 & $15,65 \%$ & 0,06 & 0,19 \\
\hline Corpus callosum agenesia/dysgenesia & 26 & 13 & $50,00 \%$ & 2 & $7,69 \%$ & 11 & $42,31 \%$ & 0,13 & 0,73 \\
\hline Spina bifida* & 72 & 64 & $88,89 \%$ & 5 & $6,94 \%$ & 3 & $4,17 \%$ & 0,07 & 0,04 \\
\hline Holoprosencephalia & 26 & 19 & $73,08 \%$ & 5 & $19,23 \%$ & 2 & $7,69 \%$ & 0,21 & 0,08 \\
\hline Dandy-Walker-malformatio/vermis hypoplasia & 14 & 9 & $64,29 \%$ & 2 & $14,29 \%$ & 3 & $21,43 \%$ & 0,18 & 0,27 \\
\hline Microcephalia & 8 & 2 & $25,00 \%$ & 1 & $12,50 \%$ & 5 & $62,50 \%$ & 0,33 & 1,67 \\
\hline Hydranencephalia & 8 & 7 & $87,50 \%$ & 0 & $0,00 \%$ & 1 & $12,50 \%$ & 0,00 & 0,14 \\
\hline Sacrococcygealis teratoma & 8 & 6 & $75,00 \%$ & 2 & $25,00 \%$ & 0 & $0,00 \%$ & 0,25 & 0,00 \\
\hline Anencephalia/exencephalia & 20 & 19 & $95,00 \%$ & 0 & $0,00 \%$ & 1 & $5,00 \%$ & 0,00 & 0,05 \\
\hline Encephalokele, meningokele & 9 & 6 & $66,67 \%$ & 1 & $11,11 \%$ & 2 & $22,22 \%$ & 0,14 & 0,29 \\
\hline Arnold-Chiari-malformatio & 2 & 0 & $0,00 \%$ & 1 & $50,00 \%$ & 1 & $50,00 \%$ & 1,00 & 1,00 \\
\hline Egyéb craniospinalis rendellenesség & 43 & 19 & $44,19 \%$ & 12 & $27,91 \%$ & 12 & $27,91 \%$ & 0,39 & 0,39 \\
\hline Összesen & 351 & 255 & $72,65 \%$ & 37 & $10,54 \%$ & 59 & $16,81 \%$ & 0,14 & 0,29 \\
\hline
\end{tabular}

${ }^{*}<0,5$ alacsony, $\geq 0,5$ magas, $\geq 1$ nagyon magas.

alatt végzett ultrahangvizsgálatok átlagos száma $3,35+$ 3,06 volt

Az 1200-ból 671 esetben végződött szüléssel a várandósság. A szülések esetében a gesztációs kor átlaga 35,26 $\pm 4,2$ hét, az újszülöttek születési súlyának átlaga pedig $2408,67 \pm 944,41$ g volt. A 671 szülésből 335 következett be a 37. terhességi hét elött $(49,93 \%)$.

A vizsgált 1200 esetból 529 esetben vetélés zajlott le. Huszonhét esetben a vetélés spontán volt, 502 magzatnál pedig indukáltan következett be. A vetélések átlagosan a 19,88 $\pm 2,53$ héten következtek be. A magzatok átlagos súlya a vetéléskor $324,03 \pm 156,07 \mathrm{~g}$ volt.

Az 1200 magzat esetében 1129 singularis, 68 gemini és 3 trigemini terhesség fordult elő. A 68 gemini esetből hatban volt érintett az ikerpár mindkét tagja (1. táblázat). A trigemini esetek mindegyikében csak egy magzat volt érintett a háromból.

Az 1200 magzatból 73-nál fordult elő kromoszómarendellenesség: 37 esetben 21-es triszómia (Downszindróma), 20 magzatnál 18-as triszómia (Edwardsszindróma), hat esetben 13 -as triszómia (Patau-szindróma), két magzatnál pedig Turner-szindróma. Nyolc magzatnál jelent meg egyéb kromoszómaeltérés: két esetben triploidia, egy esetben 9-es triszómia, egy esetben az X-kromoszóma ring formációja, egy esetben az l-es kromoszóma deletiója, három esetben pedig egyéb eltérés.

Az 1200 magzatból 211 magzatnál fordult elő multiplex malformatio: 22 magzatnál aneuploidiával együtt, míg 189 esetben euploid magzatnál. A 189-ből 133-nál a rendellenességek csak két szervrendszert érintettek, míg 64 magzatnál az érintett szervrendszerek száma mi- nimum három volt. A multiplex malformatióban szenvedő magzatoknál leggyakrabban mellkasi rendellenességek $(49,74 \%, 94$ eset), urogenitalis malformatiók $(47,09 \%, 89$ eset $)$ és craniospinalis eltérések $(44,44 \%, 84$ eset) fordultak elő.

Az 1200 magzatnál összesen 1867 rendellenesség fordult elő. A craniospinalis rendellenességek száma 351 volt, az arc és nyak malformatiói 135 esetben jelentek meg. A legnagyobb esetszámmal a mellkasi rendellenességek fordultak elő (675 eset). Kétszáznegyven eset került a hasi és hasfali rendellenességek közé, 308 az urogenitalis eltérések csoportjába, míg 158 esetet soroltunk a végtagi és csontosodási eltérésekhez.

A rendellenességek kimutathatóságának jellemezésére két új paramétert vezettünk be, a bizonytalansági faktort és nehézségi faktort.

A craniospinalis rendellenességeknél talált bizonytalansági és nehézségi faktor értékeit a 2. táblázat mutatja.

$\mathrm{Az}$ arc és nyak rendellenességeit vizsgálva minden rendellenesség-csoportban magas, illetve nagyon magas volt a nehézségi faktor, összesített értéke 1,87-nak adódott (3. táblázat).

A szív- és mellkasi rendellenességeknél számított értékeket a 4. táblázat szemlélteti.

A hasi és hasfali rendellenességek bizonytalansági és nehézségi faktor értékeit az 5. táblázat mutatja.

Az urogenitalis rendellenességeknél számított $\mathrm{F}(\mathrm{B})$ és $\mathrm{F}(\mathrm{N})$ értékeket a 6. táblázat tartalmazza.

A végtagi és csontosodási rendellenességek csoportban a nehézségi faktor összességében is magas volt, 0,7 (7. táblázat). 
3. táblázat |Craniofacialis rendellenességek praenatalis felismerésének bizonytalansági faktora $\mathrm{F}(\mathrm{B})$ és nehézségi faktora $\mathrm{F}(\mathrm{N})$

\begin{tabular}{|c|c|c|c|c|c|c|c|c|c|}
\hline \multirow[t]{2}{*}{ Rendellenesség típusa } & \multirow[t]{2}{*}{ Esetszám } & \multicolumn{2}{|c|}{ I. teljes egyezés } & \multicolumn{2}{|c|}{$\begin{array}{l}\text { II. részleges } \\
\text { egyezés }\end{array}$} & \multicolumn{2}{|c|}{ III. eltérés } & \multirow{2}{*}{$\begin{array}{c}\begin{array}{c}\text { Bizonytalansági } \\
\text { faktor } \mathrm{F}(\mathrm{B})^{*}\end{array} \\
\mathrm{II} / \mathrm{I}+\mathrm{II} \\
\end{array}$} & \multirow{2}{*}{$\begin{array}{l}\text { Nehézségi faktor } \\
\mathrm{F}(\mathrm{N})^{*} \\
\mathrm{III} / \mathrm{I}+\mathrm{II}\end{array}$} \\
\hline & & $\mathrm{n}$ & $\%$ & $\mathrm{n}$ & $\%$ & $\mathrm{n}$ & $\%$ & & \\
\hline Ajak- és szájpadhasadék & 60 & 32 & $53,33 \%$ & 1 & $1,67 \%$ & 27 & $45,00 \%$ & 0,03 & 0,82 \\
\hline Choanalis atresia & 14 & 0 & $0,00 \%$ & 1 & $7,14 \%$ & 13 & $92,86 \%$ & 1,00 & 13,00 \\
\hline Microphthalmus/anophthalmus & 9 & 2 & $22,22 \%$ & 1 & $11,11 \%$ & 6 & $66,67 \%$ & 0,33 & 2,00 \\
\hline Fülkagyló hiánya & 7 & 0 & $0,00 \%$ & 0 & $0,00 \%$ & 7 & $100,00 \%$ & & \\
\hline Micrognathia & 12 & 1 & $8,33 \%$ & 0 & $0,00 \%$ & 11 & $91,67 \%$ & 0,00 & 11,00 \\
\hline Exophthalmus & 2 & 1 & $50,00 \%$ & 0 & $0,00 \%$ & 1 & $50,00 \%$ & 0,00 & 1,00 \\
\hline Egyéb craniofacialis rendellenesség & 31 & 7 & $22,58 \%$ & 1 & $3,23 \%$ & 23 & $74,19 \%$ & 0,13 & 2,88 \\
\hline Összesen & 135 & 43 & $31,85 \%$ & 4 & $2,96 \%$ & 88 & $65,19 \%$ & 0,09 & 1,87 \\
\hline
\end{tabular}

${ }^{*}<0,5$ alacsony, $\geq 0,5$ magas, $\geq 1$ nagyon magas.

\section{Megbeszélés}

A craniospinalis rendellenességek közül az Arnold-Chiari-malformatio esetén találtunk magasabb bizonytalansági $(1,0)$ és nehézségi faktort $(1,0)$. A nehézségi faktor magas volt microcephalia $(1,67)$ és corpus callosum agenesia/dysgenesia $(0,73)$ esetén.

$\mathrm{Az}$ arc és nyak rendellenességeit vizsgálva minden rendellenesség-csoportban magas, illetve nagyon magas volt a nehézségi faktor, összesített értéke 1,87-nak adódott. Levi és mtsai saját vizsgálatukban a terhesség 26. hetéig az arc és a nyak rendellenességeit 30,56\%-ban tudták kimutatni, ami jól tükrözi az általunk számított magas nehézségi faktor értékét. A choanalis atresia csoportban nagyon magas volt mind a bizonytalansági faktor $(1,0)$, mind pedig a nehézségi faktor $(13,0)$. Nagyon magas volt a nehézségi faktor a micrognathia csoportban $(11,0)$, az egyéb craniofacialis rendellenességek esetén $(2,88)$, a microphthalmus/anophthalmus eseteknél $(2,0)$, illetve exophthalmusnál $(1,00)$. A legalacsonyabb, de még így is magas nehézségifaktor-értéket az ajak- és szájpadhasadék-csoportban találtunk $(0,82)$.

A mellkasi rendellenességeknél négy esetben, a tüdővénák malpositiója $(0,6)$, az atrialis septumdefektus $(0,54)$, a tágult jobb és bal kamra $(0,5)$, illetve a sclerosis tuberosa $(0,5)$ eseteiben találtunk magas bizonytalansági faktort. Marek és mtsai hasonló tendenciát tudtak kimutatni, a tüdővénák malpositióját például egy esetben sem tudták szülés előtt diagnosztizálni [5]. A nehézségi faktor egyedül a tüdő egyéb rendellenességeinél volt nagyon magas $(1,08)$.

A hasi és hasfali eltérések csoportban magas volt a bizonytalansági faktor az anusatresia $(0,71)$, illetve az oesophagusatresia $(0,60)$ eseteiben. A fent említett rendellenességeknél nagyon magas volt a nehézségi faktor értéke is: anusatresiánál 2,29, oesophagusatresiánál pedig 1,0. Magas nehézségi faktort találtunk továbbá az egyéb hasi és hasfali rendellenességek esetében $(0,58)$.
Fadda és mtsai az oesophagusatresiát 3/15 esetben detektálták a szülést/vetélést megelőzően (20\%), amely eredmény jól mutatja a diagnózis nehézségét és bizonytalanságát [2].

Magas volt a bizonytalansági faktor az egyéb húgyúti rendellenességek csoportban $(0,59)$. Extrém magas nehézségifaktor-értéket számoltunk a férfi genitalis rendellenességeknél (41), illetve a női genitalis rendellenességeknél is magasabb volt a nehézségi faktor $(0,5)$. Az irodalomban Fadda és mtsai vizsgálták a genitalis rendellenességek felismerhetőségét és 42,2\%-os hatékonyságot találtak, ami nem magyarázza az általunk talált extrém magas nehézségifaktor-értéket [2].

A végtagi és csontosodási rendellenességek csoportban a nehézségi faktor összességében is magas volt, 0,7 (7. táblázat). Magas volt a bizonytalansági faktor értéke polydactylia $(0,5)$ és syndactylia $(0,5)$ esetében. Nagyon magas volt a nehézségi faktor az ujj rendellenességeinél: syndactyliánál $(3,5)$ és polydactyliánál $(2,33)$, illetve az egyéb végtagi rendellenességek csoportban $(2,0)$. Dicke és mtsai alacsony szenzitivitással tudták kimutatni a polydactylia-eseteket $(19,1 \%)$ [7]. Magas nehézségi faktort találtunk továbbá a dongaláb eseteiben $(0,84)$. Rosselli és mtsa $i$ vizsgálatukban a dongalábeseteket 34,3\%-ban tudták kimutatni praenatalis ultrahangvizsgálattal, amely összhangban van az általunk számított magas nehézségifaktor-értékkel [6].

Az elvégzett ultrahangvizsgálatok nehézségeit és bizonytalansági tényezőit jól jellemzik, hogy az egyes rendellenességek felismerhetősége, a pontos diagnózis felállítása gyakran nehézségekbe ütközik, és csak a megszületés vagy vetélés után elvégzett fetopatológiai vizsgálat során állítható fel a megfelelő diagnózis. Az elvégzett vizsgálatok nemcsak a klinikánk ultrahang-laboratóriumának munkáját jellemzik, hiszen számos esetben más intézetből a progresszív betegellátás keretében került a várandós a klinikánk praenatalis diagnosztikai centrumába. Vonatkozik ez a beküldő intézetek gondos munkájára, hogy 
4. táblázat | Szív- és mellkasi rendellenességek praenatalis felismerésének bizonytalansági faktora $\mathrm{F}(\mathrm{B})$ és nehézségi faktora $\mathrm{F}(\mathrm{N})$

\begin{tabular}{|c|c|c|c|c|c|c|c|c|c|}
\hline \multirow[t]{2}{*}{ Rendellenesség típusa } & \multirow[t]{2}{*}{ Esetszám } & \multicolumn{2}{|c|}{$\begin{array}{l}\text { I. teljes } \\
\text { egyezés }\end{array}$} & \multicolumn{2}{|c|}{$\begin{array}{l}\text { II. részleges } \\
\text { egyezés }\end{array}$} & \multicolumn{2}{|c|}{ III. eltérés } & \multirow{2}{*}{$\begin{array}{l}\text { Bizonyta- } \\
\text { lansági } \\
\text { faktor } \\
\mathrm{F}(\mathrm{B})^{*} \\
\mathrm{II} / \mathrm{I}+\mathrm{II}\end{array}$} & \multirow{2}{*}{$\begin{array}{l}\text { Nehézségi } \\
\text { faktor } \\
\mathrm{F}(\mathrm{N})^{*} \\
\mathrm{III} / \mathrm{I}+\mathrm{II}\end{array}$} \\
\hline & & $\mathrm{n}$ & $\%$ & $\mathrm{n}$ & $\%$ & $\mathrm{n}$ & $\%$ & & \\
\hline Atrialis septumdefektus (ASD) & 41 & 13 & $31,71 \%$ & 15 & $36,59 \%$ & 13 & $31,71 \%$ & 0,54 & 0,46 \\
\hline Ventricularis septumdefektus (VSD) & 126 & 68 & $53,97 \%$ & 19 & $15,08 \%$ & 39 & $30,95 \%$ & 0,22 & 0,45 \\
\hline Atrioventricularis septumdefektus (AVSD) & 39 & 31 & $79,49 \%$ & 1 & $2,56 \%$ & 7 & $17,95 \%$ & 0,03 & 0,22 \\
\hline Univentricularis szív & 28 & 27 & $96,43 \%$ & 1 & $3,57 \%$ & 0 & $0,00 \%$ & 0,04 & 0,00 \\
\hline Aortastenosis & 11 & 7 & $63,64 \%$ & 3 & $27,27 \%$ & 1 & $9,09 \%$ & 0,30 & 0,10 \\
\hline Aortaatresia & 28 & 21 & $75,00 \%$ & 6 & $21,43 \%$ & 1 & $3,57 \%$ & 0,22 & 0,04 \\
\hline Coarctatio aortae & 22 & 16 & $72,73 \%$ & 3 & $13,64 \%$ & 3 & $13,64 \%$ & 0,16 & 0,16 \\
\hline Hypoplasiás balszívfél-szindróma & 40 & 36 & $90,00 \%$ & 1 & $2,50 \%$ & 3 & $7,50 \%$ & 0,03 & 0,08 \\
\hline Pulmonalis stenosis & 20 & 14 & $70,00 \%$ & 2 & $10,00 \%$ & 4 & $20,00 \%$ & 0,13 & 0,25 \\
\hline Hypoplasiás jobbszívfél-szindróma (pulmonalis atresia) & 29 & 22 & $75,86 \%$ & 6 & $20,69 \%$ & 1 & $3,45 \%$ & 0,21 & 0,04 \\
\hline Komplett nagyér-transpositio & 30 & 22 & $73,33 \%$ & 0 & $0,00 \%$ & 8 & $26,67 \%$ & 0,00 & 0,36 \\
\hline Kettős kiáramlású jobb kamra & 12 & 7 & $58,33 \%$ & 4 & $33,33 \%$ & 1 & $8,33 \%$ & 0,36 & 0,09 \\
\hline Truncus arteriosus communis & 19 & 14 & $73,68 \%$ & 4 & $21,05 \%$ & 1 & $5,26 \%$ & 0,22 & 0,06 \\
\hline Tüdővénák malpositiója & 6 & 2 & $33,33 \%$ & 3 & $50,00 \%$ & 1 & $16,67 \%$ & 0,60 & 0,20 \\
\hline Fallot-tetralógia & 19 & 13 & $68,42 \%$ & 2 & $10,53 \%$ & 4 & $21,05 \%$ & 0,13 & 0,27 \\
\hline Tricuspidalis atresia/stenosis & 7 & 5 & $71,43 \%$ & 2 & $28,57 \%$ & 0 & $0,00 \%$ & 0,29 & 0,00 \\
\hline Tricuspidalis insufficientia & 9 & 7 & $77,78 \%$ & 2 & $22,22 \%$ & 0 & $0,00 \%$ & 0,22 & 0,00 \\
\hline Mitralis atresia/stenosis & 9 & 7 & $77,78 \%$ & 2 & $22,22 \%$ & 0 & $0,00 \%$ & 0,22 & 0,00 \\
\hline Tágult jobbszív-fél & 11 & 9 & $81,82 \%$ & 2 & $18,18 \%$ & 0 & $0,00 \%$ & 0,18 & 0,00 \\
\hline Tágult jobb és bal kamra & 5 & 2 & $40,00 \%$ & 2 & $40,00 \%$ & 1 & $20,00 \%$ & 0,50 & 0,25 \\
\hline Situs inversus & 9 & 8 & $88,89 \%$ & 0 & $0,00 \%$ & 1 & $11,11 \%$ & 0,00 & 0,13 \\
\hline Szív jobbra dyslocalt & 4 & 3 & $75,00 \%$ & 1 & $25,00 \%$ & 0 & $0,00 \%$ & 0,25 & 0,00 \\
\hline Rhabdomyoma & 9 & 8 & $88,89 \%$ & 1 & $11,11 \%$ & 0 & $0,00 \%$ & 0,11 & 0,00 \\
\hline Sclerosis tuberosa & 2 & 1 & $50,00 \%$ & 1 & $50,00 \%$ & 0 & $0,00 \%$ & 0,50 & 0,00 \\
\hline Myxoma & 1 & 1 & $100,00 \%$ & 0 & $0,00 \%$ & 0 & $0,00 \%$ & 0,00 & 0,00 \\
\hline Szívaneurysma & 3 & 2 & $66,67 \%$ & 1 & $33,33 \%$ & 0 & $0,00 \%$ & 0,33 & 0,00 \\
\hline Pericardialis folyadékgyülem & 11 & 10 & $90,91 \%$ & 0 & $0,00 \%$ & 1 & $9,09 \%$ & 0,00 & 0,10 \\
\hline Szív egyéb rendellenességei & 57 & 45 & $78,95 \%$ & 8 & $14,04 \%$ & 4 & $7,02 \%$ & 0,15 & 0,08 \\
\hline Tüdő cysticus adenomatoid malformatiója & 16 & 14 & $87,50 \%$ & 1 & $6,25 \%$ & 1 & $6,25 \%$ & 0,07 & 0,07 \\
\hline Tüdő egyéb rendellenességei & 52 & 22 & $42,31 \%$ & 3 & $5,77 \%$ & 27 & $51,92 \%$ & 0,12 & 1,08 \\
\hline Összesen & 675 & 457 & $67,70 \%$ & 96 & $14,22 \%$ & 122 & $18,07 \%$ & 0,17 & 0,22 \\
\hline
\end{tabular}

${ }^{*}<0,5$ alacsony, $\geq 0,5$ magas, $\geq 1$ nagyon magas.

felismerték az adott elváltozást, de gyakran előfordult, hogy a diagnózis a klinikánkon elvégzett ultrahangvizsgálat során módosításra, pontosításra került, a vizsgálataink során ezen pontosított, a terhesség során felállított diagnózisokat vettük figyelembe. Természetesen a felismerés idôpontjaként sem a klinikán végzett ultrahangvizsgálatok idôpontját vettük elsősorban figyelembe. Amennyiben a diagnózis pontos volt és egyezett a postnatalis/ve- télés utáni diagnózissal, a pontos diagnózis felállításának időpontját vettük a teljes felismerés időpontjaként figyelembe. Amennyiben a beutaló intézetben felmerült az adott szerv rendellenessége, de a klinikánkon elvégzett ultrahangvizsgálat során is csak részben sikerült felismerni a rendellenességet, akkor a részleges felismerés időpontjaként (terhességi hét) az első vizsgálatot - amely felvetette a rendellenességet - vettük figyelembe. 
5. táblázat $\mid$ Hasi, hasfali rendellenességek praenatalis felismerésének bizonytalansági faktora $F(B)$ és nehézségi faktora $F(N)$

\begin{tabular}{|c|c|c|c|c|c|c|c|c|c|}
\hline \multirow[t]{2}{*}{ Rendellenesség típusa } & \multirow[t]{2}{*}{ Esetszám } & \multicolumn{2}{|c|}{ I. teljes egyezés } & \multicolumn{2}{|c|}{ II. részleges egyezés } & \multicolumn{2}{|c|}{ III. eltérés } & \multirow{2}{*}{$\begin{array}{c}\begin{array}{c}\text { Bizonytalansági } \\
\text { faktor } \mathrm{F}(\mathrm{B})^{*}\end{array} \\
\mathrm{II} / \mathrm{I}+\mathrm{II} \\
\end{array}$} & \multirow{2}{*}{$\begin{array}{l}\text { Nehézségi faktor } \\
\mathrm{F}(\mathrm{N})^{*} \\
\mathrm{III} / \mathrm{I}+\mathrm{II}\end{array}$} \\
\hline & & $\mathrm{n}$ & $\%$ & $\mathrm{n}$ & $\%$ & $\mathrm{n}$ & $\%$ & & \\
\hline Oesophagusatresia & 20 & 4 & $20,00 \%$ & 6 & $30,00 \%$ & 10 & $50,00 \%$ & 0,60 & 1,00 \\
\hline Duodenumatresia & 19 & 18 & $94,74 \%$ & 0 & $0,00 \%$ & 1 & $5,26 \%$ & 0,00 & 0,06 \\
\hline Egyéb bélatresia & 15 & 6 & $40,00 \%$ & 3 & $20,00 \%$ & 6 & $40,00 \%$ & 0,33 & 0,67 \\
\hline Anusatresia & 23 & 2 & $8,70 \%$ & 5 & $21,74 \%$ & 16 & $69,57 \%$ & 0,71 & 2,29 \\
\hline Gastroschisis & 12 & 12 & $100,00 \%$ & 0 & $0,00 \%$ & 0 & $0,00 \%$ & 0,00 & 0,00 \\
\hline Omphalokele & 33 & 25 & $75,76 \%$ & 3 & $9,09 \%$ & 5 & $15,15 \%$ & 0,11 & 0,18 \\
\hline Hernia diaphragmatica & 53 & 46 & $86,79 \%$ & 2 & $3,77 \%$ & 5 & $9,43 \%$ & 0,04 & 0,10 \\
\hline Hasi ciszta & 8 & 8 & $100,00 \%$ & 0 & $0,00 \%$ & 0 & $0,00 \%$ & 0,00 & 0,00 \\
\hline Egyéb & 57 & 22 & $38,60 \%$ & 14 & $24,56 \%$ & 21 & $36,84 \%$ & 0,39 & 0,58 \\
\hline Összesen & 240 & 143 & $59,58 \%$ & 33 & $13,75 \%$ & 64 & $26,67 \%$ & 0,19 & 0,36 \\
\hline
\end{tabular}

${ }^{*}<0,5$ alacsony, $\geq 0,5$ magas, $\geq 1$ nagyon magas.

6. táblázat $\mid$ Urogenitalis rendellenességek praenatalis felismerésének bizonytalansági faktora $\mathrm{F}(\mathrm{B})$ és nehézségi faktora $\mathrm{F}(\mathrm{N})$

\begin{tabular}{|c|c|c|c|c|c|c|c|c|c|}
\hline \multirow[t]{2}{*}{ Rendellenesség típusa } & \multirow[t]{2}{*}{ Esetszám } & \multicolumn{2}{|c|}{ I. teljes egyezés } & \multicolumn{2}{|c|}{$\begin{array}{l}\text { II. részleges } \\
\text { egyezés }\end{array}$} & \multicolumn{2}{|c|}{ III. eltérés } & \multirow{2}{*}{$\begin{array}{c}\begin{array}{c}\text { Bizonytalansági } \\
\text { faktor } \mathrm{F}(\mathrm{B})^{*}\end{array} \\
\mathrm{II} / \mathrm{I}+\mathrm{II}\end{array}$} & \multirow{2}{*}{$\begin{array}{l}\text { Nehézségi faktor } \\
\qquad \mathrm{F}(\mathrm{N})^{*} \\
\text { III } / \mathrm{I}+\mathrm{II}\end{array}$} \\
\hline & & $\mathrm{n}$ & $\%$ & $\mathrm{n}$ & $\%$ & $\mathrm{n}$ & $\%$ & & \\
\hline Pyelectasia & 61 & 41 & $67,21 \%$ & 3 & $4,92 \%$ & 17 & $27,87 \%$ & 0,07 & 0,39 \\
\hline Egyéb obstruktív elváltozás & 36 & 32 & $88,89 \%$ & 3 & $8,33 \%$ & 1 & $2,78 \%$ & 0,09 & 0,03 \\
\hline Multicystás vesedysplasia & 36 & 29 & $80,56 \%$ & 4 & $11,11 \%$ & 3 & $8,33 \%$ & 0,12 & 0,09 \\
\hline Polycystás vesedysplasia & 9 & 9 & $100,00 \%$ & 0 & $0,00 \%$ & 0 & $0,00 \%$ & 0,00 & 0,00 \\
\hline Agenesia/hypoplasia renis & 61 & 32 & $52,46 \%$ & 11 & $18,03 \%$ & 18 & $29,51 \%$ & 0,26 & 0,42 \\
\hline Egyéb húgyúti rendellenesség & 39 & 11 & $28,21 \%$ & 16 & $41,03 \%$ & 12 & $30,77 \%$ & 0,59 & 0,44 \\
\hline Férfi genitalis & 42 & 1 & $2,38 \%$ & 0 & $0,00 \%$ & 41 & $97,62 \%$ & 0,00 & 41,00 \\
\hline Női genitalis & 24 & 13 & $54,17 \%$ & 3 & $12,50 \%$ & 8 & $33,33 \%$ & 0,19 & 0,50 \\
\hline Összesen & 308 & 168 & $54,55 \%$ & 40 & $12,99 \%$ & 100 & $32,47 \%$ & 0,19 & 0,48 \\
\hline
\end{tabular}

${ }^{*}<0,5$ alacsony, $\geq 0,5$ magas, $\geq 1$ nagyon magas.

7. táblázat |Végtag-rendellenességek és csontosodási zavarok praenatalis felismerésének bizonytalansági faktora $\mathrm{F}(\mathrm{B})$ és nehézségi faktora $\mathrm{F}(\mathrm{N})$

\begin{tabular}{|c|c|c|c|c|c|c|c|c|c|}
\hline \multirow[t]{2}{*}{ Rendellenesség típusa } & \multirow[t]{2}{*}{ Esetszám } & \multicolumn{2}{|c|}{ I. teljes egyezés } & \multicolumn{2}{|c|}{$\begin{array}{l}\text { II. részleges } \\
\text { egyezés }\end{array}$} & \multicolumn{2}{|c|}{ III. eltérés } & \multirow{2}{*}{$\begin{array}{c}\begin{array}{c}\text { Bizonytalansági } \\
\text { faktor } \mathrm{F}(\mathrm{B})^{*}\end{array} \\
\mathrm{II} / \mathrm{I}+\mathrm{II}\end{array}$} & \multirow{2}{*}{$\begin{array}{l}\text { Nehézségi faktor } \\
\qquad \mathrm{F}(\mathrm{N})^{*} \\
\text { III } / \mathrm{I}+\mathrm{II}\end{array}$} \\
\hline & & $\mathrm{n}$ & $\%$ & $\mathrm{n}$ & $\%$ & $\mathrm{n}$ & $\%$ & & \\
\hline Végtagreductio & 17 & 11 & $64,71 \%$ & 4 & $23,53 \%$ & 2 & $11,76 \%$ & 0,27 & 0,13 \\
\hline Dongaláb (pes equinovarus) & 35 & 18 & $51,43 \%$ & 1 & $2,86 \%$ & 16 & $45,71 \%$ & 0,05 & 0,84 \\
\hline Arthrogryposis & 6 & 5 & $83,33 \%$ & 0 & $0,00 \%$ & 1 & $16,67 \%$ & 0,00 & 0,20 \\
\hline Polydactylia & 20 & 3 & $15,00 \%$ & 3 & $15,00 \%$ & 14 & $70,00 \%$ & 0,50 & 2,33 \\
\hline Syndactylia & 9 & 1 & $11,11 \%$ & 1 & $11,11 \%$ & 7 & $77,78 \%$ & 0,50 & 3,50 \\
\hline Egyéb végtag-rendellenesség & 30 & 7 & $23,33 \%$ & 3 & $10,00 \%$ & 20 & $66,67 \%$ & 0,30 & 2,00 \\
\hline Osteogenesis imperfecta & 5 & 4 & $80,00 \%$ & 1 & $20,00 \%$ & 0 & $0,00 \%$ & 0,20 & 0,00 \\
\hline Egyéb csontosodási zavar & 36 & 30 & $83,33 \%$ & 1 & $2,78 \%$ & 5 & $13,89 \%$ & 0,03 & 0,16 \\
\hline Összesen & 158 & 79 & $50,00 \%$ & 14 & $8,86 \%$ & 65 & $41,14 \%$ & 0,15 & 0,70 \\
\hline
\end{tabular}

${ }^{*}<0,5$ alacsony, $\geq 0,5$ magas, $\geq 1$ nagyon magas. 


\section{Következtetések}

A vizsgálat során megállapíthattuk, hogy a magzati craniospinalis rendellenességek és mellkasi eltérések nagy hatékonysággal vizsgálhatók a méhen belüli magzatnál (72,65\% és 67,7\%). Magas szenzitivitással tudtuk kimutatni a hasi malformatiókat $(59,58 \%)$, az urogenitalis rendellenességeket $(54,55 \%)$, illetve a végtag- és csontrendszeri eltéréseket (50\%). Ezzel szemben az arc és nyak rendellenességeinek kimutatása alacsony hatékonyságú volt $(31,85 \%)$.

Az általunk bevezetett bizonytalansági faktor $\mathrm{F}(\mathrm{B})$ és nehézségi faktor $\mathrm{F}(\mathrm{N})$ jól jellemezte a praenatalis ultrahangvizsgálat nehézségeit. Magas értékeket kaptunk az arc és végtagok eltéréseinél, amelyek az irodalmi adatok alapján is a nehezebben kimutatható rendellenességek közé tartoznak. Magas volt a bizonytalansági faktor eredménye a corpus callosum agenesia/dysgenesia csoportnál, amely csoportban az irodalmi adatok alapján is nehéz a pontos diagnózis, általában ventriculomegalia/ hydrocephalus az egyetlen, praenatalisan is diagnosztizált eltérés.

Anyagi támogatás: Dr. Erős Fanni Rebeka a Prof. Dr. Regöly-Mérei János Alapítvány pályázatának különdíjasaként kapott felkérést a közlemény megírására.

Szerzôi munkamegosztás: E. F. R.: Az adatok gyűjtése, feldolgozása, a közlemény megírása. B. A.: A kutatás vezetése, adatok feldolgozása, a táblázatok szerkesztése, a közlemény megírása, klinikai genetikai szakrendelés keretein belül a betegek gondozása, a tudományos kutatómunka koordinálása. A cikk végleges változatát mindkét szerző elolvasta és jóváhagyta.

Érdekeltség: A szerzőknek nincsenek érdekeltségeik.

\section{Köszönetnyilvánítás}

A betegséggel érintett családoknak és az ultrahangvizsgálatok egy részét végző Siposné Radványi Zsuzsának, illetve az ultrahanglabor munkatársainak mondunk köszönetet.

\section{Irodalom}

[1] Levi S. Ultrasound in prenatal diagnosis: polemics around routine ultrasound screening for second trimester fetal malformations. Prenat Diagn. 2002; 22: 285-295.

[2] Fadda GM, Capobianco G, Balata A, et al. Routine second trimester ultrasound screening for prenatal detection of fetal malformations in Sassari University Hospital, Italy: 23 years of experience in 42,256 pregnancies. Eur J Obstet Gynecol Reprod Biol. 2009; 144: 110-114.

[3] Van Dorsten JP, Hulsey TC, Newman RB, et al. Fetal anomaly detection by second-trimester ultrasonography in a tertiary center. Am J Obstet Gynecol. 1998; 178: 742-749.

[4] Saltvedt S, Almström H, Kublickas M, et al. Detection of malformations in chromosomally normal fetuses by routine ultrasound at 12 or 18 weeks of gestation-a randomised controlled trial in 39,572 pregnancies. BJOG 2006; 113: 664-674.

[5] Marek J, Tomek V, Skovranek J, et al. Prenatal ultrasound screening of congenital heart disease in an unselected national population: a 21-year experience. Heart 2011; 97: 124-130.

[6] Rosselli P, Nossa S, Huérfano E, et al. Prenatal ultrasound diagnosis of congenital talipes equinovarus in Bogota (Colombia) between 2003 and 2012. Iowa Orthop J. 2015; 35: 156-159.

[7] Dicke JM, Piper SL, Goldfarb CA. The utility of ultrasound for the detection of fetal limb abnormalities - a 20-year single-center experience. Prenat Diagn. 2015; 35: 348-353.

[8] Papp Z, Tóth-Pál E, Papp C, et al. Impact of prenatal mid-trimester screening on the prevalence of fetal structural anomalies: a prospective epidemiological study. Ultrasound Obstet Gynecol. 1995; 6: 320-326.

[9] Beke A, Papp Cs, Tóth-Pál E, et al. Cytogenetic exploration of fetal ultrasound anomalies. [Ultrahangvizsgálattal észlelt magzati anomáliák citogenetikai feltárása.] Orv Hetil. 2004; 145: 21232133. [Hungarian]

[10] Papp Cs, Bán Z, Szigeti Zs, et al. The role of ultrasonography in second trimester screening for fetal chromosome aberrations. [A terhesség második trimeszterében végzett ultrahangvizsgálat szerepe a magzati kromoszóma-rendellenességek szúrésében.] Orv Hetil. 2006; 147: 2131-2137. [Hungarian]

(Beke Artúr dr., e-mail: beke.artur@noil.sote.hu)

\title{
Háziorvosi körzet
}

\author{
Albertirsán - a 4-es számú főút mentén Budapesttől 50 km-re lévő kertvárosban - \\ nyugdíjba vonulás miatt eladó vagy átadó egy 1800 kártyás háziorvosi körzet. \\ A rendelő néhány éve teljesen felújított, modern, kompletten felszerelt. \\ Parkolási lehetőség megoldott. Gyógyszertár közvetlenül a rendelő mellett. \\ A városban szolgálati lakás megoldható. \\ Érdeklődni lehet: + 36/70 371-0451; irsapraxis@citromail.hu
}

